\title{
United in Autonomy? The Question of EU Internal Enlargement
}

\author{
Merijn Chamon*
}

\section{Introduction}

Before setting out some observations on the topic which was assigned to me, I would like to start with a general disclaimer: the problem which we are discussing today is, ultimately, a fundamentally political issue. Discussing the legal challenges which an EU region vying for independence will encounter inevitably draws one into political questions. However, in my intervention I will try to keep a clear legal focus, leaving the political issues to the political actors.

Turning to the assigned topic, it is worth pointing out the assumptions which underlie the question on 'internal enlargement'. Thus, should a region of an EU Member State become independent, it would indeed be in the economic and political interest of that region to try and secure its own EU membership as fast and smoothly as possible, as a matter of self-preservation. Secondly, the notion of enlargement already hints at the hurdles which such a region would have to overcome, similarly to the challenges faced by a third country when it applies for membership of the EU under Article 49 TEU.

\section{Internal enlargement of fragmentation?}

That said, it is also worthwhile to further ponder on the notion of internal enlargement and whether it is an apt term to qualify the process at issue, given that there is no real 'enlargement' of the EU involved. Indeed 'internal enlargement' rather seems to be a euphemism for 'fragmentation', since the situation whereby the territorial scope of the EU would remain the same, but with a greater number of constituent entities (i.e. Member States), seems better captured by the notion of fragmentation. ${ }^{1}$ Fundamentally, fragmentation also sits uneasily with the EU's basic tenet of 'ever closer union'. Ultimately, a secessionist region would reject a close bilateral union within its mother state, only to subscribe to an ever closer multilateral union involving that same (ex-)mother state. ${ }^{2}$

The basic legal challenge for regions such as Scotland, Catalonia and Flanders then is that the EU Treaties do not formally allow (or foresee) a scenario of fragmentation. Post-Lisbon, the only scenarios legally provided for under EU primary law are those of (genuine) enlargement and contraction under Articles 49 and 50 TEU. Fragmentation then is a combination of these two, whereby a part of an EU Member State secedes from the EU (cf. infra) only to adhere to the EU as a Member State in its own right.

\section{An international law perspective and the Quebec opinion of the Canadian Supreme Court}

Given that the EU Treaties are silent on fragmentation, it is interesting to verify how the problem at hand should be looked at from an international law perspective. I will be brief on this, since it has largely been covered by professor De Feyter. As regards the right to self-determination it should be pointed out that, assuming that citizens living in Scotland, Flanders or Catalonia may be qualified as peoples, this right does not automatically entail a right to an own state. Under international law, a people should first exercise its right to self-determination within its state. The devolution processes in the UK, Belgium and Catalonia already show that these states accommodate the wish for selfdetermination of its citizens living in Scotland, Flanders or Catalonia. A remedial right of secession from the mother state then only exists for colonised peoples or for those peoples that are being collectively denied their civil and political rights, being subject to egregious abuses by their mother

\footnotetext{
${ }^{*}$ Academic Assistant and $\mathrm{PhD}$ researcher at the Ghent European Law Institute.

${ }^{1}$ See for this and a more elaborate discussion of the topic: MERIJN CHAMON AND GuILlaume VAN DER LOO, 'The Temporal Paradox of Regions in the EU Seeking Independence: Contraction and Fragmentation versus Widening and Deepening?', (2014) 20 European Law Journal 5, p. 614.

${ }^{2}$ Ibid.
} 
state. ${ }^{3}$ However, the EU membership of the UK, Belgium and Spain, and the conditions related thereto, almost ipso facto means that groups living in those Member States do not come under this scenario.

So far for the legal context. In the end, regardless of legal principles and rules which may apply, politics may trump law. This was as such also recognised by the Canadian Supreme Court when it was asked to analyse the possibility of Quebec leaving the Canadian federation. While the Court found no such right for the Quebecois, neither under Canadian nor under international law, it still remarked that a clear expression of the Quebecois for independence could not be ignored by the other entities in the Canadian federation, ${ }^{4}$ and in the event of a unilateral non-negotiated secession its success "would be dependent on recognition by the international community, which is likely to consider the legality and legitimacy of secession having regard to, amongst other facts, the conduct of Quebec and Canada, in determining whether to grant or withhold recognition." As Sir David Edward has stressed in his observations on the secessionist movements within the EU Member States, a negotiated settlement between the region in question and its mother state indeed amounts to a condition sine qua non for a successful secession. ${ }^{6}$

\section{Back to square one: fragmentation under EU law}

International law therefore is not very helpful to solve the question of fragmentation in the EU and ultimately international law also refers back to the law of the international organisation in question when it is confronted with a problem of state succession in treaty law. ${ }^{7}$ This means we are back to square one: international law refers back to the EU Treaties themselves, but these Treaties are silent on the possibility and procedures for fragmentation. As already noted, fragmentation seems a combination of contraction (Article $50 \mathrm{TEU}$ ) and enlargement (Article $49 \mathrm{TEU}$ ) which may have led top EU politicians such as Barroso and Van Rompuy to state (in their personal capacity) that a secessionist region would fall outside the EU on the moment of its independence and that it would have to (re-)apply to become an EU Member State. ${ }^{8}$ Bourgeois rightly notes that the region in question would not fall outside the EU from one day to the next, but that it would have to negotiate its withdrawal under Article 50 TEU. ${ }^{9}$ Since EU regions only form part of the EU by virtue of their link with the actual EU Member States. Here one of the fundamental tenets in EU law should be recalled: the EU is simply composed of Member States whereby the internal organisation of those states is a matter exclusive to them. The EU will then not interfere in domestic affairs but neither will it accord special importance to the internal statute of entities within their Member State, regardless of their internal autonomy or independence. ${ }^{10}$ Seceding from a Member State then also involves seceding from the EU, but in order to secede from the EU, the Treaty of Lisbon now provides in a pre-defined procedure which, as a result, would have to be followed by the region in question. ${ }^{11}$

\footnotetext{
${ }^{3}$ MiCHAEL SCHARF, 'Earned Sovereignty: Juridical Underpinnings', (2003) 31 Denver International Journal of Law and Policy 3, p. 381.

${ }^{4}$ Reference re Secession of Quebec [1998] S. C. R. 217, para. 151.

${ }^{5}$ Ibid. para. 155 .

${ }^{6}$ DAVID EDward, 'EU Law and the Separation of Member States', 2013 (36) Fordham International Law Journal 5, pp. 1151-1168.

${ }^{7}$ See Article 4 of the Vienna Convention on Succession of States in Respect of Treaties, UN GA, 1978, UN Doc. A/Conf. 80/31 (1978).

${ }^{8}$ See Letter of José Manuel Barroso to Lord Tugendhat (Economic Affairs Committee), 10 December 2012; Remarks by President of the European Council Herman Van Rompuy on Catalonia, 12 December 2013, PRESSE 576, PR PCE 241. For a critique on these positions, see DAVID EDWARDS, op. cit.; JACQUES BOURGEOIS, Redactionele signalen, (2014) 62 SEW Tijdschrift voor Europees en economisch recht, 4, p. 161. For an earlier genuine Commission position on this issue, see Commission Answer to Written Question P0524/04 by Eluned Morgan (PSE), O. J. 2004 C 84E/421.

${ }^{9}$ BOURGEOIS, op. cit., p. 161.

${ }^{10}$ See i.a. CFI, Netherlands Antilles v. Commission, T-41/98, [2000] ECR II-201, para. 43 and cases cited.

${ }^{11}$ While Article 50 TEU only refers to a Member State (and not part of a Member State) withdrawing from the $\mathrm{EU}$, the Article would also govern the withdrawal of an EU region from the EU. See CHAMON AND VAN DER LOO, op. cit., pp. 621-2.
} 
While the repercussions of such a scenario would be hard for the secessionist regions, it is difficult to find another legal solution to the problem. The fact that the regions in question have formed part of the EU for decades, or were even part of the founding states, is legally irrelevant since the only relevant constituent elements of the EU are the Member States (cf. supra). Further, the scenario applied to East-Germany's 'accession' to the EU cannot serve as a precedent either since it resulted in the opposite of a fragmentation: the territorial scope of the EU widened but the number of constituent entities remained the same. It further resulted, for a brief period, in the underrepresentation of Germany in the EU institutions. Of course, the other Member States would be more willing to accept the underrepresentation of a Member State than that state's overrepresentation, which would happen in case of fragmentation. ${ }^{12}$

The Scottish government itself proposes to solve the legal conundrum through a Treaty based on Article 48 TEU, i.e. an amendment to the EU Treaties themselves rather than an accession agreement. Through a Treaty amendment then, the post-independence EU membership of a region could be secured. ${ }^{13}$ However, in the EU legal order, it is impossible for the EU to comprise a greater number of Member States than the number of States between which it is established. ${ }^{14}$ The Scottish solution, relying on Article 48 TEU, would mean that the UK would introduce an amendment on behalf of the to be independent Scots (whether this is politically realistic is another thing) and following a unanimity with the other 27 Member States (again whether this is politically realistic is another thing) that Scotland would become a member of the EU without having signed and ratified an accession treaty. The EU would be composed of 29 Member States while only being established by 28 states.

\section{Invoking Article 2 TEU}

The Scottish government has also invoked Article 2 TEU on the values of the EU, i.a. human rights, freedom and democracy, thereby suggesting that the EU somehow should respect the result of Scottish independence, given that the process towards Scottish independence would be wholly consistent with these values. ${ }^{15}$ While the latter may be true, it suffices to note that even if the EU were required to recognise Scottish independence this is no way amounts to having to accept an independent Scottish state as a member of the EU. If democracy could serve as such a trump card, what would prevent EU Member States to unilaterally declare opt-outs from the EU Treaties through plebiscites, irrespective of any procedure foreseen in the Treaties?

\section{Fragmentation, in who's interest?}

In absence of a clear legal solution it should again be pointed out that fragmentation may be made legally possible, as long as there is a political agreement between the relevant actors. Yet, the political merits of fragmentation are also uncertain. Looking at the EU, it not clear why fragmentation would be in its interest: it would not enlarge (broadening the internal market) but its internal functioning would be more difficult since it would i.a. bring at least one new Commissioner to the table and one new veto player in the (European) Council (under unanimity rules). However, as the Scottish government points out, it would not be in the EU's interest either to shut out secessionist regions ${ }^{16}$ (after all, this would also make the internal market shrink) but this still means that the EU's interest in fragmentation is mixed at best and far from unequivocally positive. The other Member States would have the same mixed reasons for supporting or frustrating a smooth process to EU membership for the regions in question. For some Member States the principles of territorial integrity and state sovereignty and the

\footnotetext{
${ }^{12}$ Merijn Chamon And Guillaume VAn Der Loo, op. cit., p. 620.

13 The Scottish Government, Scotland in the European Union, pp. 86-7 (available at: http://www.scotland.gov.uk/Resource/0043/00439166.pdf).

${ }^{14}$ ECJ, Région wallonne v. Commission, C-95/97 [1997] ECR I-1787, para 6.

${ }^{15}$ Scotland in the European Union, op. cit., p. 1.

${ }^{16}$ Ibid. pp. 1-2.
} 
fear of setting a precedent might weigh so heavily that they would set a high price for the region in question to secure EU membership. This price would then presumably have to be paid, since every existing Member State (including the Member State from which a region secedes) ${ }^{17}$ would have a veto right. Of course, it is difficult to imagine that regions such as Scotland, Flanders and Catalonia could be kept out of the EU indefinitely as this would be politically untenable. However, the fact remains that these regions would be in a weak position to make any demands since their EU membership depends on unanimity and the remaining Member State can (ab)use this rule to secure their own interests. Here it would seem crucial that the regions in question engage in paradiplomatic efforts (cf. the intervention of Mr. Dauwen) well before actually deciding on independence.

Without commenting too much on this political issue, it may be noted that some supporters and sympathizers of the 'YES-campaign' systemically dismiss these observations as 'scare-mongering' by the other side. While some 'NO-campaigners' will undoubtedly (have) resort(ed) to this tactic, such a riposte is an all too easy way to ignore some fundamental challenges which an independent Scotland, Flanders, Catalonia, etc. will have to overcome. This is not to say that the Scottish government should be berated for not providing clear answers to these challenges. Indeed as discussed here and elsewhere, ${ }^{18}$ the problem precisely is that no one can deliver such answers. Supporters of both side should then have the intellectual honesty to admit that some issues do not have a pre-defined outcome. Fully conscious of the existence of these uncertainties and risks (on a number of fundamental issues for the region's future), it would then be up to the citizens to decide whether they are willing to take them or not.

Perhaps surprisingly, it should also be verified whether fragmentation would be in the interest of the newly independent states themselves. One often heard reason is that EU Membership in their own right would allow those regions to have a say at the EU table. While this would indeed be the case, such a say would be rather small. If a de facto rather than a de iure say is the most important, it could be more interesting to work out certain arrangements for EU participation within the region's Member State, as has been done in Belgium. ${ }^{19}$ Secondly, there is the legal concept of reverse discrimination in EU law. Simply put: EU law does not permit a Member State to discriminate against nationals from other Member States. However EU law does not stand in the way of a Member State discriminating against its own nationals. Again, because to the EU only the Member State is relevant, the rule of reverse discrimination also applies to a situation whereby part of a Member State (e.g. Scotland or Flanders) discriminates against those State's nationals from another part of that Member State (e.g. England or Wallonia). Such discriminations are internal affairs which are not caught by EU law as also confirmed by the Court of Justice in the Flemish Care Insurance case. ${ }^{20}$ Flanders for instance, in order to preserve its Dutch-speaking character, has elaborated different policies that discriminate (in a legal sense) against (Belgian) French speakers. As long as Flanders remains part of Belgium, these policies are (partially) saved by the concept of reverse discrimination. However, should Flanders become an EU Member State in its own right, these policies will be scrutinised for their effects on the EU's fundamental freedoms and any restrictions found will have to be justified. Ironically, from a legal perspective, it would appear easier for Flanders to preserve its Dutch-speaking character as an integral part of Belgium than it would be as an independent EU Member State. Lastly, although this is more linked to the strategy for independence and EU membership, rather than to these objectives, the Scottish government's self-imposed goal of securing EU membership within a period of 18 months would seem ill-advised given the political context in which EU membership would have to be secured

\footnotetext{
${ }^{17}$ It may be argued that in the Flemish case, Belgium would simply dissolve. It is clear however that it would be in the interest of the remainder of Belgium (Brussels and Wallonia) to continue as Belgium. This in itself would also be a political and diplomatic issue, rather than a legal one.

${ }^{18}$ See CHAMON AND VAN DER LOO, op. cit., pp. 613-29.

${ }^{19}$ See Bart KerRemans, 'Belgium', in: Peters AND Wright, The national co-ordination of EU policy: the domestic level, Oxford, Oxford University Press, 2000, pp. 182-200.

${ }^{20} \mathrm{ECJ}$, Gouvernement de la Communauté française et Gouvernement wallon v. Gouvernement flamand, C212/06, [2008] ECR I-1683.
} 
(cf. supra). A secessionist region already being in a weak position vis-à-vis its mother state and the other Member States, claiming not only EU membership but EU membership within 18 months from an independence referendum only drives up the price which other Member States may demand.

\section{Concluding remarks}

In political discourse, semantics is important and this is why pro-independence campaigners resort to the concept of internal enlargement when discussing future EU membership. The actual scenario, should it materialise, would however be better described by fragmentation since the EU would not enlarge and would simply be composed of more entities.

The basic legal challenge for internal enlargement/fragmentation is that it is not foreseen under the EU Treaties and instead seems a combination of the two categories that are foreseen, i.e. enlargement and withdrawal. With legal uncertainty rampant, at least one thing is clear: fragmentation is subject to unanimity between the Member States.

While allowing for fragmentation is not in the interest of the EU, it might be politically impossible to disallow fragmentation when the citizens living in a specific EU region have expressed strong support for independence (which threshold indicates 'strong support' is a wholly different question). The legally most sound solution would then be a combination of Articles 49 and 50 TEU, if possible simultaneously applied. ${ }^{21}$

\footnotetext{
${ }^{21}$ Here one could be faced with a temporal problem, since it seems difficult to apply Articles 49 and 50 TEU simultaneously even if this would be in the interest of both the region in question and the EU. See CHAMON AND VAN DER LOO, op. cit., p. 628.
} 